J Biophotonics. 2012 November ; 5(11-12): 827-837. doi:10.1002/jbio.201200077.

\title{
Transcranial low level laser (light) therapy for traumatic brain injury
}

\author{
Ying-Ying Huang ${ }^{1,2,3}$, Asheesh Gupta ${ }^{1,2,4}$, Daniela Vecchio ${ }^{1,2}$, Vida J. Bil de Arce ${ }^{1}$, Shih- \\ Fong Huang ${ }^{1,2,5}$, Weijun Xuan ${ }^{1,2,6}$, and Michael R. Hamblin ${ }^{\star}, 2,7$ \\ ${ }^{1}$ Wellman Center for Photomedicine, Massachusetts General Hospital, BAR414, 40 Blossom \\ Street, Boston, MA 02114, USA \\ ${ }^{2}$ Department of Dermatology, Harvard Medical School, Boston, MA 02115, USA \\ ${ }^{3}$ Aesthetic and Plastic Center of Guangxi Medical University, Nanning, China \\ ${ }^{4}$ Defence Institute of Physiology and Allied Sciences, Timarpur, Delhi-110 054, India \\ ${ }^{5}$ Taipei Veterans General Hospital, Beitou District, Taipei City, Taiwan 112 \\ ${ }^{6}$ Department of Otolaryngology, Traditional Chinese Medical University of Guangxi, Nanning, \\ China \\ ${ }^{7}$ Harvard-MIT Division of Health Sciences and Technology, Cambridge, MA 02139, USA
}

\section{Abstract}

We review the use of transcranial low-level laser (light) therapy (LLLT) as a possible treatment for traumatic-brain injury (TBI). The basic mechanisms of LLLT at the cellular and molecular level and its effects on the brain are outlined. Many interacting processes may contribute to the beneficial effects in TBI including neuroprotection, reduction of inflammation and stimulation of neurogenesis. Animal studies and clinical trials of transcranial-LLLT for ischemic stroke are summarized. Several laboratories have shown that LLLT is effective in increasing neurological performance and memory and learning in mouse models of TBI. There have been case report papers that show beneficial effects of transcranial-LLLT in a total of three patients with chronic TBI. Our laboratory has conducted three studies on LLLT and TBI in mice. One looked at pulsedvs-continuous wave laser-irradiation and found $10 \mathrm{~Hz}$ to be superior. The second looked at four different laser-wavelengths $(660,730,810$, and $980 \mathrm{~nm})$; only 660 and $810 \mathrm{~nm}$ were effective. The last looked at different treatment repetition regimens (1,3 and 14-daily laser-treatments).

\section{Graphical Abstract}

Schematic of transcranial LLLT employed for stroke.

\footnotetext{
*Corresponding author: hamblin@helix.mgh.harvard.edu, Phone: 617-726-6182, Fax: 617-726-8566.
} 


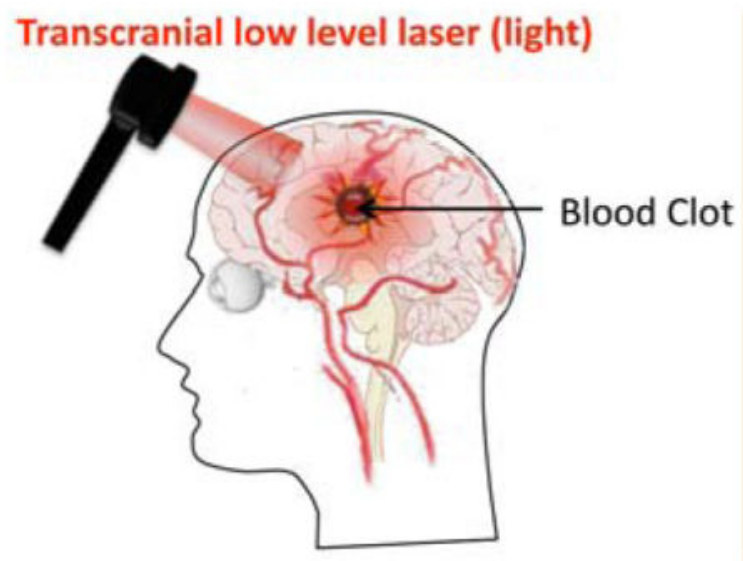

\section{Keywords}

Low level laser therapy; photobiomodulation; NIR laser; traumatic brain injury; stroke; mouse models; neurogenesis; clinical trials

\section{Introduction}

Traumatic brain injury (TBI) includes skull fractures, intracranial hemorrhages, elevated intracranial pressure, and cerebral contusion. Unlike stroke, which is often associated with senior citizens, TBI affects a predominantly young population. Severe and moderate TBI, whether accidental or inflicted, is a major health and socio-economic problem throughout the world. In the United States alone, approximately 2 million injuries occur each year resulting in 56,000 deaths and 18,000 survivors suffering from permanent neurological impairment [1-3]. The consequent direct and indirect annual costs in the US are estimated at $\$ 56$ billion [4]. The World Health Organization (WHO) has projected that by 2020, road traffic accidents, a major cause of TBI, will rank third as a cause of the global burden of disease and disablement, behind only ischemic heart disease and unipolar major depression [5]. Despite advances in our understanding of the pathophysiological damage that occurs following brain injury, current treatments are limited both in their efficacy and utility [6]. The pathophysiology of TBI is very complex and still poorly understood. Immediately following the primary impact, activation of several different pathways begins, resulting in secondary brain injury. These include inflammation, oxidative stress, ionic imbalance, increased vascular permeability, mitochondrial dysfunction and excitotoxic damage [7]. These processes result in brain edema, increased intracranial pressure and impaired cerebral perfusion. This combination of cellular and physiologic disturbances causes increased neuronal cell death, enlargement of infarct size and neurological, motor and cognitive impairment. Efforts to improve the treatment and outcome of TBI must therefore remain the priority for clinicians and researches [8].

Although TBI is a severe health concern, the search for better therapies in the recent years has not been successful. This has led to interest in more radical alternatives to existing procedures, such as transcranial low level-laser (light) therapy (LLLT). There have been a 
number of papers showing that transcranial LLLT can ameliorate brain damage in stroke models such as middle cerebral artery occlusion in rats and after clot injection in rabbits.

\section{Mechanisms of LLLT}

In low level-laser (light) therapy (LLLT) the question is no longer whether light has biological effects but rather how light energy from lasers or LEDs works at the cellular and organism levels and what are the optimal parameters for different applications of these light sources for different diseases. Several postulated mechanisms seem unlikely: heat production, although closely associated with lasers, did not appreciably elevate brain temperature in preclinical studies, suggesting that photothermal effects do not play a role [17]. Therefore, photochemistry became a widely accepted hypothesis to explain the induction of photobiological processes in cells via absorption of light energy [9]. Any effect ultimately relies on the absorption of light by chromophores within the cell to produce biological effects including increased energy within cells in the form of ATP, increased deoxyribonucleic acid (DNA) and ribonucleic acid (RNA), nitric oxide (NO) release, more cytochrome c oxidase activity, modulation of reactive oxygen species (ROS), modifications to intracellular organelle membrane activity particularly in mitochondria, calcium flux and stress proteins [18-22]. Moreover, in tissue there is an "optical window" that runs approximately from $600 \mathrm{~nm}$ to $1200 \mathrm{~nm}$ where the effective tissue penetration of light is maximized. Therefore the use of LLLT in animals and patients almost exclusively involves red and near-infrared light $(600-1100 \mathrm{~nm})$ [10].

Mitochondria are perhaps the single most important organelle within cells governing the LLLT response. In addition to acting as the cellular energy supply, mitochondria are involved in a range of other processes, such as signaling, cellular differentiation, cell death, as well as the control of the cellular metabolism and cell proliferation. Action spectra (a plot of biological effect against wavelength) identified the relevant chromophore by matching the biological response to light in the visble/NIR range to the absorption spectra of the four membrane-bound complexes identified in mitochondria [11]. This procedure indicates that complex IV on the mitochondrial inner membrane, also known as cytochrome $c$ oxidase (CCO), is the crucial chromophore in the cellular response to LLLT [10]. CCO is a large transmembrane protein complex, consisting of two copper centers and two heme-iron centers, which is a component of the respiratory electron transport chain [12]. The precise manner in which laser light affects CCO is not yet known. The effects of LLLT on both cells and tissues will undoubtedly involve a complex cascade of pathways with altered intracellular signaling and changes to redox states. Mitochondrial ROS may act as a modulatable redox signal, reversibly affecting the activity of a range of functions in the mitochondria, cytosol and nucleus. LLLT was reported to produce a shift in overall cell redox potential in the direction of greater oxidation [13] and increased ROS generation and cell redox activity have been demonstrated [14]. Several transcription factors are regulated by changes in cellular redox state. Among them are redox factor -1 (Ref-1), activator protein-1 (AP-1) (a heterodimer of $c$-Fos and $c$-Jun), nuclear factor kappa B (NF- $\mathrm{BB}$ ), p53, activating transcription factor/cAMP-response element-binding protein (ATF/CREB), hypoxia-inducible factor (HIF)-1, and HIF-like factor. LLLT induced ROS have been proposed to be involved in regulation of activation of redox-sensitive early/intermediate 
genes and related transcription factors including NF- $\mathrm{kB}$ [15]. One important feature of LLLT that has been repeatedly reported is its intrinsic biphasic dose-response curve [16, 17]. In other words although a small amount of light is good, delivering more light may lose the beneficial effects of the low levels of light, and delivering a lot more light might actually be harmful. This effect could be explained by the "Janus" effect of two of the proposed mediators of LLLT signaling; ROS [18] and NO [19]. Both these species have been proposed to be beneficial in low concentrations but can be actually harmful in high doses.

Another possible regulator of cell signaling, nitric oxide (NO) has also been observed to be released from cells during LLLT. It is possible that LLLT may cause photodissociation of NO from CCO [20, 21]. Cellular respiration is down-regulated by the production of NO by mitochondrial NO synthase (mtNOS, a NOS isoform specific to mitochondria), that binds to $\mathrm{CCO}$ and inhibits it. The NO displaces oxygen from $\mathrm{CCO}$, inhibiting cellular respiration and thus decreasing the production of ATP [22]. By dissociating NO from CCO, LLLT prevents this process from taking place and results in increased ATP production [23, 24]. Therefore, at the tissue level light can influence blood flow, following release of the vasodilator, NO [24]. Enhanced perfusion will facilitate improved oxygenation and recruitment of inflammation cells to the areas undergoing repair as well as further re-vascularization and proliferation of cells to achieve systemic effect. Figure 1 graphically illustrates some of the intracellular signaling pathways that are proposed to occur after LLLT.

More specific mechanisms of LLLT need to be discussed when it is used as a transcranial approach for disorders of the brain. Figure 2 illustrates some of the possible brain-specific mechanisms of transcranial LLLT for TBI. Cortical neurons in the injured or damaged brain are proposed to be prevented from dying by the cytoprotective effects of LLLT that have been widely reported including reduction of neuronal cell death due to cyanide [25], tetrodotoxin [26], and methanol [27]. The mediators of this protective effect may include such inducible proteins such as survivin [28], Bcl2, heat shock proteins [29] and superoxide dismutase [30]. Other processes associated with LLLT that may be beneficial in TBI include the anti-inflammatory effect of LLLT, thought to include down-regulation of proinflammatory mediators from dendritic cells [31], and the increase of suppressor cells secreting anti-inflammatory mediators such as IL10 and TGF-beta [32]. Another process related to LLLT that may be important in TBI is its pro-angiogenic effect that has been well documented in wound healing and similar studies [33-35]. Neurogenesis or neuroplasticity (synaptogenesis) may be an additional mechanism of action contributing toward improved outcomes after transcranial LLLT to the brain [36]. These processes may be stimulated by increased expression of neurotrophins such as BDNF and NGF.

\section{Transcranial LLLT for stroke and TBI}

Stroke is a leading cause of death in the world and a common reason for hospitalization. The approved treatment for stroke is administration of tissue plasminogen activator within 3 hours from stroke onset $[37,38]$. The short time available to intervene, reduces the opportunity to treat many patients and only 5\% of patients receive the therapy [39]. Many studies have been carried out to investigate alternative treatments for stroke. 
LLLT has been investigated as an alternative treatment for stroke. Several studies have demonstrated that LLLT can modulate many biological processes [40-42], and can have a cardioprotective effects $[43,44]$.

Light can penetrate several tissues, including the scalp and skull into the brain; preclinical and clinical studies have demonstrated improved recovery after stroke [45]. Stroke was induced with two different methods in rat and rabbit models. In rats, stroke was produced using permanent middle cerebral artery occlusion (MCAO) through craniotomy or insertion of a filament in carotid artery [46, 47]. The data obtained in some of these studies demonstrated that intervening with LLLT $24 \mathrm{~h}$ after acute stroke could provide significant benefits. In other studies, stroke was induced in rabbits using the small clot embolic stroke model (RSCEM) injecting a blood microclot prepared from blood drawn from a donor rabbit [48]. In these models, the light was administered transcranially with a laser probe was placed in direct contact with the skin. These studies, treatments and results are summarized in Table 1.

Two clinical studies have been carried out in human patients. In the first one called NEST-1, 120 patients were involved. The study required to patients to be between 40 to 85 years of age with a diagnosis of ischemic stroke and a measurable neurological deficit. Laser irradiation $(808 \mathrm{~nm}$ ) was delivered to the whole head in 20 sequential spots each lasting for 2 minutes as shown in Figure 3. The patients in LLLT group received the treatment within $24 \mathrm{~h}$ of stroke onset. This first clinical trial demonstrated the safety and effectiveness of LLLT [49]. In the second clinical trial, NEST-2, 660 patients were randomized into two groups (331 LLLT group and 327 sham group) [50]. The results of NEST-1 and 2 clinical studies are reported in Table 2.

\section{Transcranial LLLT studies for TBI in mice}

The success of transcranial LLLT for stroke encouraged researchers to test the technique in animal models of TBI. Oron and coworkers evaluated the effects of LLLT for TBI in mice. Closed-head injury of mice was induced by using a weight-drop device. An 808-nm Gs-As diode laser with two different energy density $\left(1.2-2.4 \mathrm{~J} / \mathrm{cm}^{2}\right.$ over 2 minutes irradiation with 10 and $20 \mathrm{~mW} / \mathrm{cm}^{2}$ ) was delivered to the brain $4 \mathrm{~h}$ after TBI. Neurobehavioral function was assessed by neurological severity score (NSS). There was no statistical difference in NSS between the power density of 10 and $20 \mathrm{~mW} / \mathrm{cm}^{2}$. There was no significant difference between control/non-laser-treated group and laser-irradiated group at $24 \mathrm{~h}$ and 48 hours post $\mathrm{CHI}$. There was a significant improvement in neurobehavioral function in the laser-irradiated groups from day 5 up to day 28, where the NSS were 26-27\% lower in the laser-irradiated group. The laser-treated group showed a lower loss $(1.4 \%)$ of cortical tissue at the injured site compared to the sham control group $(12.1 \%)(P<0.001)$. This study suggested that transcranial LLLT significantly reduced long-term neurological deficits [51].

Moreira et al. reported the effect of low intensity laser phototherapy on local and systemic immuno-modulation following cryogenic brain injury in rat. The rats were irradiated with 780 and $660 \mathrm{~nm}$ laser on 3 and $5 \mathrm{~J} / \mathrm{cm}^{2}$. This study concluded that LLLT could modulate 
TNF-alpha, IL-6 and IL-beta concentrations in the brain and blood of rats with cryogenic brain injury [52].

Khuman and coworkers proved treatment of low level laser therapy could improve cognitive deficits after controlled cortical impact in mice. The controlled cortical impact was induced by a $3 \mathrm{~mm}$ flat-tipped pneumatic piston at a velocity of $6 \mathrm{~m} / \mathrm{sec}$ and a depth of $0.6 \mathrm{~mm}$, for 100 millisecond duration. The mice were randomly assigned to open craniotomy group underwent $800 \mathrm{~nm}$ low-level laser irradiation with different energy level $(30,60,105,120$, 210 , and $0 \mathrm{~J} / \mathrm{cm}^{2}$ ) at $60-80 \mathrm{~min}$ after CCI or transcranial group underwent $60 \mathrm{~J} / \mathrm{cm}^{2}$ at different time points (60-80 mins or $4 \mathrm{~h}$ after CCI, or one treatment per day for 7 days). Cognitive function by Morris water maze (MWM), motor function by wire grip test, brain edema, lesion volume, nitrosative stress by nitrotyrosine ELISA were assessed. Mice with CCI treated with $60 \mathrm{~J} / \mathrm{cm}^{2}\left(500 \mathrm{~mW} / \mathrm{cm}^{2} \times 2 \mathrm{~min}\right)$ had significant improvement of the latency to the hidden platform and probe trails either via an open craniotomy or transcranially. An anti-inflammatory effect was noted via a significant reduction of microgliosis at $48 \mathrm{~h}$ with $60 \mathrm{~J} / \mathrm{cm}^{2}$ LLLT. There was no significant difference on motor function (day 1 to 7 ), brain edema ( $24 \mathrm{~h}$ ), nitrosative stress ( $24 \mathrm{~h}$ ), or lesion volume (14 days) between LLLT and control group [53].

Oron et al. [54] next examined the long-term effect of various transcranial laser therapy modes (pulsed versus continious) and at different treatment time points in mild to moderate closed-head injury mice (NSS 4-6) induced using a weight-drop device. A Ga-Al-As 808 $\mathrm{nm}$ wavelength laser with an energy level of $1.2 \mathrm{~J} / \mathrm{cm}^{2}\left(10 \mathrm{~mW} / \mathrm{cm}^{2}\right.$ for $\left.2 \mathrm{~min}\right)$ was delivered $4 \mathrm{~h}, 6 \mathrm{~h}, 8 \mathrm{~h}$ post injury transcranially. Another experiment the laser was applied at a dose of $10 \mathrm{~mW} / \mathrm{cm}^{2}$ at $100 \mathrm{~Hz}, 600 \mathrm{~Hz}$ or continuous wave $4 \mathrm{~h}$ post-CHI. The difference in NSS of the laser treated group $6 \mathrm{~h}$ and $8 \mathrm{~h}$ post injury were 3.4- and 1.8-fold that in control nontreated group at day 56. Compared to control non-treated group, there were an approximately 3.5-flod increase in difference in NSS for all three modes laser therapy (100 $\mathrm{Hz}, 600 \mathrm{~Hz}$, and CW). The mice received transcranial LLLT with PW at $100 \mathrm{~Hz} 4 \mathrm{~h}$ post injury have the highest full recovery (NSS 0) percentage (67\%) at day 56. The lesion size was significant smaller in both $\mathrm{CW}$ and PW laser treated group than control group on MRI [54].

\section{TBI case report studies in humans}

Red or near-infra-red light at wavelengths can penetrate tissue $1 \mathrm{~cm}$ deep through the skin or scalp (based on post-mortem studies), thus the brain cortex is estimated to receive 2 to $3 \%$ of the incident light. Naeser et al. treated two chronic, TBI patients in a clinical case study [55, 56]. The pioneering LLLT case study reported improvement without formal testing in the first patient via patient narratives such as length of time for continued attention span (minutes able to work on a computer from 30 to 4 hours), "to remember what she read" and improved mathematical abilities and decreased sensitivity to scalp during hair cuts depending on the specific area where the $19.39 \mathrm{~cm}^{2}$, continuous wave $(\mathrm{CW}), 25.8 \mathrm{~mW} / \mathrm{cm}^{2}$, $500 \mathrm{~mW}$ total power red/NIR light emitting diodes (LED) was applied to the forehead as shown in Figure 4. Improved sleep and better control of social behavior was common for both TBI patients undergoing red/NIR LLLT LED treatments applied bilaterally and to 
midline sagittal areas [55]. After 9 months of similar treatment differing by using $22.48 \mathrm{~cm}^{2}$, $22.2 \mathrm{~mW} / \mathrm{cm}^{2}$ power density, the second patient showed statistically significant improvement over prior neuropsychological testing ( +2 SD for two areas of the Stroop test for executive function, where before treatment she scored below average $9^{\text {th }}$ to $63^{\text {rd }}$ percentile, in two areas: inhibition and inhibition accuracy. +1 SD improvement was measured on the Wechsler Memory Scale test, logical memory passage, an area where she was already well above average, $83^{\text {rd }}$ to $99^{\text {th }}$ percentile, before/after treatment) [55].

Another case study used single-photon emission computed tomography with $\mathrm{N}$-isopropyl(123I) $p$-iodoamphetamine (IMP-SPECT) to quantify cerebral blood flow reported by Nawashiro et al. in 2012 [57]. They treated a single patient in a "persistent vegetative state following severe head injury" with 146 LED treatments over 73 days from an array of $23 \times$ $850 \mathrm{~nm}$ LED, $13 \mathrm{~mW}$ each, held $5 \mathrm{~mm}$ from the skin, $30 \mathrm{~min}$ per session, the power density was $11.4 \mathrm{~mW} / \mathrm{cm}^{2}$; the and the energy density was $20.5 \mathrm{~J} / \mathrm{cm}^{2}$ at the skin. After bilateral LED treatment to the forehead above the brow, a unilateral, left anterior frontal lobe focal increase of $20 \%$ in cerebral blood flow was observed. They also observed the movement of the left arm of the patient who had been previously in a persistent vegetative state.

Both these studies Nawashiro et al. [57] and Naeser et al. [55] reported significant improvement and no adverse effects, other than sleepiness in the conscious patients which dissipated after one week, and switching the time of the treatment to just before bed. This is despite a potentially wide variety of factors: (1) time since brain injury varied from 2 years vs. 7 years; (2) cause(s) of injury (one motor vehicle accident vs. several injuries without loss of consciousness (LOC) rugby, sky diving, military deployment and one concussion with LOC (falling onto concrete from a swing); (3) co-morbidities of depression and suicidal ideation vs. post traumatic stress disorder (PTSD); and (4) functional severity based on patient performance (vegetative state vs. defined as medically disabled enough for government medical disability payments vs. unable to concentrate longer than 20 minutes and (4) different medications (Concerta begun several years before LED treatment (Pt. 1), Lexapro which was exchanged for Ritalin (30 mg per day) 3 months after LED beginning treatments, in addition to Provigil, Armour thyroid replacement, liquid glutathione and twice weekly vitamin B injections (Pt. 2)). Larger clinical studies are needed to gather a much larger cohort of patients to determine the factors that influence TBI treatment response based on level of severity, area of brain affected and altered function, in order to better quantify how transcranial LLLT affects persons with TBI. Quantitative measures may include MRI, IMPSPECT and neuropsychiatric testing before and after treatment. Consistency among authors for quantifying the extent and location of brain injury or changes in cerebral blood flow will be needed.

\section{Effect of different laser wavelengths in transcranial LLLT in closed head TBI model in mice}

The following sections will summarize studies from our laboratory that have explored the use of transcranial LLLT to treat TBI in animal models. 
Wu and colleagues [58] investigated the effect of different wavelengths of LLLT for closedhead TBI in mice. Closed-head injury was induced by using a weight drop apparatus.

Moderate to severe degree TBI mice by assessing neurological severity score (NSS) 6-8 one hour post-injury randomly received a single irradiation with $665,730,810$, or $980 \mathrm{~nm}$ laser with $36 \mathrm{~J} / \mathrm{cm}^{2}\left(150 \mathrm{~mW} / \mathrm{cm}^{2}\right.$ over $\left.4 \mathrm{~min}\right)$ at $4 \mathrm{~h}$ after contusion. 665 and $810 \mathrm{~nm}$ groups showed significant improvements of NSS than sham-treated control group after day 5 to day 28 as shown in Figure 5. The mean fractional areas of brain determined by morphometry for 665 and $810 \mathrm{~nm}$ LLLT groups was significantly decreased compared to the fractional area for the sham-treated control group at day 28. [58]. NIR lasers at 730 or $980 \mathrm{~nm}$ did not produce the same beneficial effects on NSS [58]. The principal tissue chromophore that is proposed to be responsible for photobiomodualtion effects induced by LLLT is cytochrome $\mathrm{c}$ oxidase (CCO). CCO has distinct absorption bands in the red $(\sim 665 \mathrm{~nm})$ and in the NRI $(\sim 810 \mathrm{~nm})$, and there is a minimum CCO absorption spectrum at $730 \mathrm{~nm}$ [59]. Furthermore, the study mentioned that $980 \mathrm{~nm}$ laser did not produce the same positive effect. However, other previous reports have shown that $980 \mathrm{~nm}$ was an active wavelength in LLLT applications. Wu et al. suggested that ineffectiveness of $980 \mathrm{~nm}$ in their study might be due to use of different laser dosimetry (irradiance, energy density etc.) selected for their study [58].

\section{Effect of pulsing in LLLT for controlled cortical impact (CCI)-TBI in mice}

Although many studies have shown common consensus on the best wavelengths of laser for treatment of brain disorders, and a range of accepted dosages to be used (irradiance and fluence), however there is no consensus on whether continuous wave or pulse light is best and on what factors govern the pulse parameters to be chosen. Ando and colleagues [60] compared the same $810 \mathrm{~nm}$ laser parameters delivered in different modes, either pulsed at 10 $\mathrm{Hz}$ or at $100 \mathrm{~Hz}$ with $50 \%$ duty cycle compared with continuous wave $(\mathrm{CW})$ laser in a mouse TB I model. TBI was induced by a controlled cortical-impact device through an open craniotomy. The head was closed up and 4 hours after injury LLLT was delivered to the top of the head using a 1-cm diameter spot. They used an $810 \mathrm{~nm} \mathrm{Ga-Al-As} \mathrm{diode} \mathrm{laser} \mathrm{with} \mathrm{a}$ single exposure with an average power density of $50 \mathrm{~mW} / \mathrm{cm}^{2}$ for 12 minutes giving a total fluence of $36 \mathrm{~J} / \mathrm{cm}^{2}$. At 48 hours to 28 days after TBI, the neurological severity score (NSS) showed a significant decrease in all laser treated groups. The improvement in the $10 \mathrm{~Hz}$ group became greater than in the PW $100 \mathrm{~Hz}$ and CW groups after day 7 as shown in Figure 6. The PW $10 \mathrm{~Hz}$ group showed a significant decrease of immobility time in the forced swim test for depression and anxiety compared to the untreated TBI group at day 28 . There was a significant decrease of the immobility periods of the tail suspension test (another measure of depression and anxiety) in the PW $10 \mathrm{~Hz}$ group compared with untreated TBI group at day 1 and 28. These results suggest the antidepressant effect of LLLT. The significant decrease of lesion size in brain tissue around the traumatized site was noted at the PW $10 \mathrm{~Hz}$ group at day 15 and 28. It implied LLLT has a neuroprotective effect at the early stage of TBI. The therapeutic effects including the severity of injury, the antidepressant effects and protection of brain tissue of LLLT for TBI with $810 \mathrm{~nm}$ laser was more effective at $10 \mathrm{~Hz}$ pulse frequency than the $100 \mathrm{~Hz}$ and continuous wave. Ando et al. also hypothesized that a possible reason why laser irradiation at $10 \mathrm{~Hz}$ pulsed mode was most effective for improving 
neurological outcome is that the frequency affects the whole brain. Resonance may occur between the frequency of the pulsed light and that of the brain waves. Particularly relevant is the fact that oscillation of theta waves that have a prominent $4-10 \mathrm{~Hz}$ rhythm in the hippocampal region of all mammals [61].

\section{Effects of transcranial LLLT repetition regimen in CCI-TBI in mice}

The efficacy of LLLT on TBI has been previously investigated to a limited extent. However there are still many questions to be solved, for example, what is the best regimen of treatment repetition? It is well established during 40 years of LLLT studies that there is a pervasive biphasic dose response relationship that applies not only in cell culture studies, but also in preclinical animal studies and even in clinical reports [62]. It has been found that there is generally an optimum level of energy density $\left(\mathrm{J} / \mathrm{cm}^{2}\right)$, power density $\left(\mathrm{mW} / \mathrm{cm}^{2}\right)$ and/or treatment repetition required to give the best therapeutic effects. A less than optimal choice of parameters can results in reduced effectiveness of the treatment, or even a negative therapeutic outcome [40].

Xuan et al. (W. Xuan, L. Huang, Q. Wu, Y. Xuan, T. Dai, T. Ando, T. Xu, Y-Y. Huang, and M. R. Hamblin, 2012, submitted for publication) used a CCI mouse model of severe TBI, and studied the effects of different treatment repetitions of $810 \mathrm{~nm}$ LLLT on neurobehavioral and vestibulomotor functioning, histomorphological analysis and histological evidence of neuroprotection and neurogenesis. The animals of the TBI treatment groups received transcranial LLLT (continuous wave $810 \mathrm{~nm}$ laser, $25 \mathrm{~mW} / \mathrm{cm}^{2}, 18 \mathrm{~J} / \mathrm{cm}^{2}$ ) either once at 4 hours post-TBI, 3 treatments (once a day for 3 days) or 14 treatments (once a day for 14 days). They found that LLLT may have beneficial effects in the acute treatment of TBI and demonstrated that mice with severe TBI treated with once laser treatment (and to a greater extent 3 daily laser) had significant improvements in NSS, and wire-grip and motion test. However 14 daily laser treatments provided no benefit. Furthermore, the study reported LLLT for TBI in mice could significantly improve neural function, decrease lesion volume, augment cell proliferation, and even protect the brain against neuronal damage to some degree.

\section{Conclusion}

Evidence that transcranial LLLT is a beneficial treatment for acute TBI is rapidly accumulating. The large number of published studies that transcranial LLLT is effective for acute stroke suggested that the same approach would also be effective for acute TBI which shares many of the pathophysiological features found in ischemic stroke. The benefits of transcranial LLLT appear to be based on many different biological mechanisms. Neuroprotection or the ability of the laser to prevent the spread of brain cell death that occurs in the hours and days after a brain lesion is formed, is shown by the smaller size of the lesion area in LLLT treated mice. Anti-inflammatory, anti-edema and proangiogenic effects of LLLT may also have roles to play in the beneficial effects. Perhaps the most exciting possible beneficial mechanism is that LLLT may stimulate neurogenesis or increase the ability of the brain to repair itself. Not only may new brain cells be formed after LLLT but the existing brain cells may be encouraged to form new synaptic connections in the 
process known as synaptogenesis or synaptic plasticity. If these processes can be reliably shown to occur after transcranial LLLT it opens the door to the treatment being applied to neurodegenerative diseases such as Alzheimer's and many diverse psychiatric disorders.

\section{Acknowledgments}

Supported by NIH grant R01AI050875, Center for Integration of Medicine and Innovative Technology (DAMD17-02-2-0006), CDMRP Program in TBI (W81XWH-09-1-0514) and Air Force Office of Scientific Research Military Photomedicine Program (FA9550-11-1-0331).

\section{References}

1. Sosin DM, Sniezek JE, Thurman DJ. Brain Inj. 1996; 10:47-54. [PubMed: 8680392]

2. Bruns J Jr, Hauser WA. Epilepsia. 2003; 44(Suppl 10):2-10.

3. Kraus JF, McArthur DL. Neurol Clin. 1996; 14:435-450. [PubMed: 8827181]

4. Thurman DJ, Alverson C, Dunn KA, Guerrero J, Sniezek JE. J Head Trauma Rehabil. 1999; 14:602-615. [PubMed: 10671706]

5. Finfer SR, Cohen J. Resuscitation. 2001; 48:77-90. [PubMed: 11162885]

6. Vink R, Nimmo AJ. Neurotherapeutics. 2009; 6:28-42. [PubMed: 19110197]

7. Zink BJ, Szmydynger-Chodobska J, Chodobski A. The Psychiatric clinics of North America. 2010; 33:741-756. [PubMed: 21093676]

8. Marklund N, Hillered L. Br J Pharmacol. 2011; 164:1207-1229. [PubMed: 21175576]

9. Sutherland JC. Photochem Photobiol. 2002; 76:164-170. [PubMed: 12194212]

10. Karu TI, Afanas'eva NI. Dokl Akad Nauk. 1995; 342:693-695. [PubMed: 7670387]

11. Karu TI. IEEE J Quantum Electron. 1987; 23:1703-1717.

12. Capaldi RA, Malatesta F, Darley-Usmar VM. Biochim Biophys Acta. 1983; 726:135-148. [PubMed: 6307356]

13. Karu TI. J Photochem Photobiol B. 1999; 49:1-17. [PubMed: 10365442]

14. Lubart R, Eichler M, Lavi R, Friedman H, Shainberg A. Photomed Laser Surg. 2005; 23:3-9. [PubMed: 15782024]

15. Chen AC, Arany PR, Huang YY, Tomkinson EM, Sharma SK, Kharkwal GB, Saleem T, Mooney D, Yull FE, Blackwell TS, Hamblin MR. PLoS ONE. 2011; 6:e22453. [PubMed: 21814580]

16. Dai T, Huang YY, Hamblin MR. Photodiagnosis Photodyn Ther. 2009; 6:170-188. [PubMed: 19932449]

17. Obrenovitch TP, Urenjak J. J Neurotrauma. 1997; 14:677-698. [PubMed: 9383088]

18. Khuman J, Zhang J, Park J, Carroll JD, Donahue C, Whalen MJ. J Neurotrauma. 2011

19. Mungrue IN, Stewart DJ, Husain M. Circ Res. 2003; 93:e74. [PubMed: 14525922]

20. Lane N. Nature. 2006; 443:901-903. [PubMed: 17066004]

21. Karu TI, Pyatibrat LV, Afanasyeva NI. Lasers Surg Med. 2005; 36:307-314. [PubMed: 15739174]

22. Antunes F, Boveris A, Cadenas E. Proc Natl Acad Sci USA. 2004; 101:16774-16779. [PubMed: 15546991]

23. Zhang R, Mio Y, Pratt PF, Lohr N, Warltier DC, Whelan HT, Zhu D, Jacobs ER, Medhora M, Bienengraeber M. J Mol Cell Cardiol. 2009; 46:4-14. [PubMed: 18930064]

24. Lohr NL, Keszler A, Pratt P, Bienengraber M, Warltier DC, Hogg N. J Mol Cell Cardiol. 2009; 47:256-263. [PubMed: 19328206]

25. Liang HL, Whelan HT, Eells JT, Meng H, Buchmann E, Lerch-Gaggl A, Wong-Riley M. Neuroscience. 2006; 139:639-649. [PubMed: 16464535]

26. Wong-Riley MT, Liang HL, Eells JT, Chance B, Henry MM, Buchmann E, Kane M, Whelan HT. J Biol Chem. 2005; 280:4761-4771. [PubMed: 15557336]

27. Eells JT, Henry MM, Summerfelt P, Wong-Riley MT, Buchmann EV, Kane M, Whelan NT, Whelan HT. Proc Natl Acad Sci USA. 2003; 100:3439-3444. [PubMed: 12626762] 
28. Hemvani N, Chitnis DS, Bhagwanani NS. Photomed Laser Surg. 2005; 23:571-574. [PubMed: 16356149]

29. Coombe AR, Ho CT, Darendeliler MA, Hunter N, Philips JR, Chapple CC, Yum LW. Clin Orthod Res. 2001; 4:3-14. [PubMed: 11553080]

30. Malinovskaya SL, Monich VA, Artifeksova AA. Bull Exp Biol Med. 2008; 145:573-575. [PubMed: 19145284]

31. Chen AC, Huang YY, Sharma SK, Hamblin MR. Photomed Laser Surg. 2011; 29:383-389. [PubMed: 21214383]

32. Rocha AM Junior, Vieira BJ, de Andrade LC, Aarestrup FM. Photomed Laser Surg. 2009; 27:303307. [PubMed: 19382837]

33. Bossini PS, Fangel R, Habenschus RM, Renno AC, Benze B, Zuanon JA, Neto CB, Parizotto NA. Lasers Med Sci. 2009; 24:209-213. [PubMed: 18351431]

34. Corazza AV, Jorge J, Kurachi C, Bagnato VS. Photomed Laser Surg. 2007; 25:102-106. [PubMed: 17508845]

35. Garavello I, Baranauskas V, da Cruz-Hofling MA. Histol Histopathol. 2004; 19:43-48. [PubMed: 14702170]

36. Pearson-Fuhrhop KM, Kleim JA, Cramer SC. Top Stroke Rehabil. 2009; 16:282-299. [PubMed: 19740733]

37. Thom T, Haase N, Rosamond W, Howard VJ, Rumsfeld J, Manolio T, Zheng ZJ, Flegal K, O’Donnell C, Kittner S, Lloyd-Jones D, Goff DC Jr, Hong Y, Adams R, Friday G, Furie K, Gorelick P, Kissela B, Marler J, Meigs J, Roger V, Sidney S, Sorlie P, Steinberger J, WasserthielSmoller S, Wilson M, Wolf P. Circulation. 2006; 113:e85-e151. [PubMed: 16407573]

38. Marler J. N Engl J Med. 1995; 333:1581-1587. [PubMed: 7477192]

39. Hacke W, Kaste M, Bluhmki E, Brozman M, Davalos A, Guidetti D, Larrue V, Lees KR, Medeghri Z, Machnig T, Schneider D, von Kummer R, Wahlgren N, Toni D. N Engl J Med. 2008; 359:13171329. [PubMed: 18815396]

40. Chung H, Dai T, Sharma SK, Huang YY, Carroll JD, Hamblin MR. Ann Biomed Eng. 2012; 40:516-533. [PubMed: 22045511]

41. Conlan MJ, Rapley JW, Cobb CM. J Clin Periodontol. 1996; 23:492-496. [PubMed: 8783057]

42. Mirsky N, Krispel Y, Shoshany Y, Maltz L, Oron U. Antioxid Redox Signal. 2002; 4:785-790. [PubMed: 12470506]

43. Oron U, Yaakobi T, Oron A, Mordechovitz D, Shofti R, Hayam G, Dror U, Gepstein L, Wolf T, Haudenschild C, Haim SB. Circulation. 2001; 103:296-301. [PubMed: 11208692]

44. Yaakobi T, Shoshany Y, Levkovitz S, Rubin O, Ben Haim SA, Oron U. J Appl Physiol. 2001; 90:2411-2419. [PubMed: 11356808]

45. Leung MC, Lo SC, Siu FK, So KF. Lasers Surg Med. 2002; 31:283-288. [PubMed: 12355575]

46. Oron A, Oron U, Chen J, Eilam A, Zhang C, Sadeh M, Lampl Y, Streeter J, DeTaboada L, Chopp M. Stroke. 2006; 37:2620-2624. [PubMed: 16946145]

47. Zhang L, Chen J, Li Y, Zhang ZG, Chopp M. J Neurol Sci. 2000; 174:141-146. [PubMed: 10727700]

48. Lapchak PA, Wei J, Zivin JA. Stroke. 2004; 35:1985-1988. [PubMed: 15155955]

49. Lampl Y, Zivin JA, Fisher M, Lew R, Welin L, Dahlof B, Borenstein P, Andersson B, Perez J, Caparo C, Ilic S, Oron U. Stroke. 2007; 38:1843-1849. [PubMed: 17463313]

50. Zivin JA, Albers GW, Bornstein N, Chippendale T, Dahlof B, Devlin T, Fisher M, Hacke W, Holt W, Ilic S, Kasner S, Lew R, Nash M, Perez J, Rymer M, Schellinger P, Schneider D, Schwab S, Veltkamp R, Walker M, Streeter J. Stroke. 2009; 40:1359-1364. [PubMed: 19233936]

51. Oron A, Oron U, Streeter J, de Taboada L, Alexandrovich A, Trembovler V, Shohami E. J Neurotrauma. 2007; 24:651-656. [PubMed: 17439348]

52. Moreira MS, Velasco IT, Ferreira LS, Ariga SK, Barbeiro DF, Meneguzzo DT, Abatepaulo F, Marques MM. J Photochem Photobiol B. 2009; 97:145-151. [PubMed: 19800810]

53. Khuman J, Zhang J, Park J, Carroll JD, Donahue C, Whalen MJ. J Neurotrauma. 2012; 29:408417. [PubMed: 21851183] 
54. Oron A, Oron U, Streeter J, De Taboada L, Alexandrovich A, Trembovler V, Shohami E. J Neurotrauma. 2012; 29:401-407. [PubMed: 22040267]

55. Naeser MA, Saltmarche A, Krengel MH, Hamblin MR, Knight JA. Photomed Laser Surg. 2010

56. Naeser MA, Saltmarche A, Krengel MH, Hamblin MR, Knight JA. Photomed Laser Surg. 2011; 29:351-358. [PubMed: 21182447]

57. Nawashiro H, Wada K, Nakai K, Sato S. Photo-med Laser Surg. 2012; 30:231-233.

58. Wu Q, Xuan W, Ando T, Xu T, Huang L, Huang YY, Dai T, Dhital S, Sharma SK, Whalen MJ, Hamblin MR. Lasers Surg Med. 2012; 44:218-226. [PubMed: 22275301]

59. Karu TI, Pyatibrat LV, Kolyakov SF, Afanasyeva NI. J Photochem Photobiol B. 2005; 81:98-106. [PubMed: 16125966]

60. Ando T, Xuan W, Xu T, Dai T, Sharma SK, Kharkwal GB, Huang YY, Wu Q, Whalen MJ, Sato S, Obara M, Hamblin MR. PLoS One. 2011; 6:e26212. [PubMed: 22028832]

61. Sushko BS, Lymans'kyi Iu P, Huliar SO. Fiziol Zh. 2007; 53:51-60. [PubMed: 17725044]

62. Huang YY, Chen AC, Carroll JD, Hamblin MR. Dose Response. 2009; 7:358-383. [PubMed: 20011653]

63. Detaboada L, Ilic S, Leichliter-Martha S, Oron U, Oron A, Streeter J. Lasers Surg Med. 2006; 38:70-73. [PubMed: 16444697]

64. Lapchak PA, Salgado KF, Chao CH, Zivin JA. Neuroscience. 2007; 148:907-914. [PubMed: 17693028]

\section{Biographies}

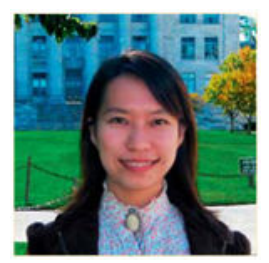

Ying-Ying Huang, M.D., has been a postdoctoral fellow in Dr. Hamblin's laboratory for four years. Her research interests lie in cellular mechanisms of low-level light therapy. She has published over 20 peer review articles.

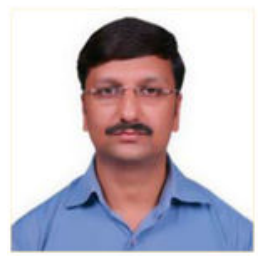

Asheesh Gupta, Ph.D. is Scientist at DIPAS (DRDO), India. Currently, he is a postdoctoral fellow in Dr. Hamblin's laboratory. His research interests lie in wound healing, regeneration, biomaterials and low level light therapy. He has published over 17 peer-reviewed articles. 


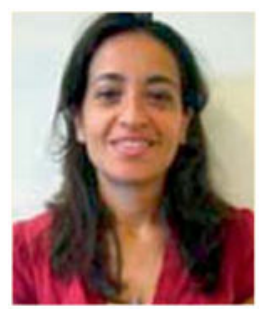

Daniela Vecchio, Ph.D. is currently a postdoctoral fellow in Dr. Hamblin's laboratory. Her research interests the antimicrobial effect of photodynamic therapy in in vivo and in vitro studies and wound healing. She has published 7 peer-reviewed articles.

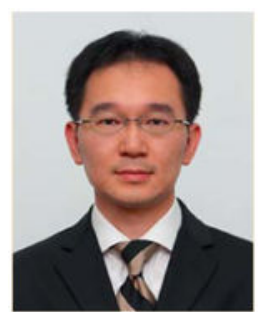

Shih-Fong Huang, M.D., is an attending physiatrist at the neurological institute in Taipei Veterans General Hospital in Taiwan. He is at present a visiting scientist in Dr. Hamblins laboratory at Wellman Center for Photomedicine. He studies the application of low level laser therapy in traumatic brain injury, stroke, spinal cord injury and peripheral neuropathy.

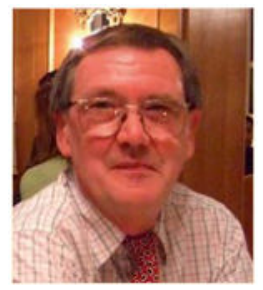

Michael R. Hamblin Ph.D. is a Principal Investigator at the Wellman Center for Photomedicine at Massachusetts General Hospital, an Associate Professor of Dermatology at Harvard Medical School and is a member of the affiliated faculty of the Harvard-MIT Division of Health Science and Technology. His research interests lie in the areas of photodynamic therapy for infections, cancer, and heart disease and in low-level light therapy for wound healing, arthritis, traumatic brain injury and hair regrowth. He directs a laboratory of around a dozen post-doctoral fellows, visiting scientists and graduate students. He has published 168 peer-reviewed articles, over 150 conference proceedings, book chapters and International abstracts and holds 8 patents. In 2011 Dr. Hamblin was honored by election as a Fellow of SPIE. 


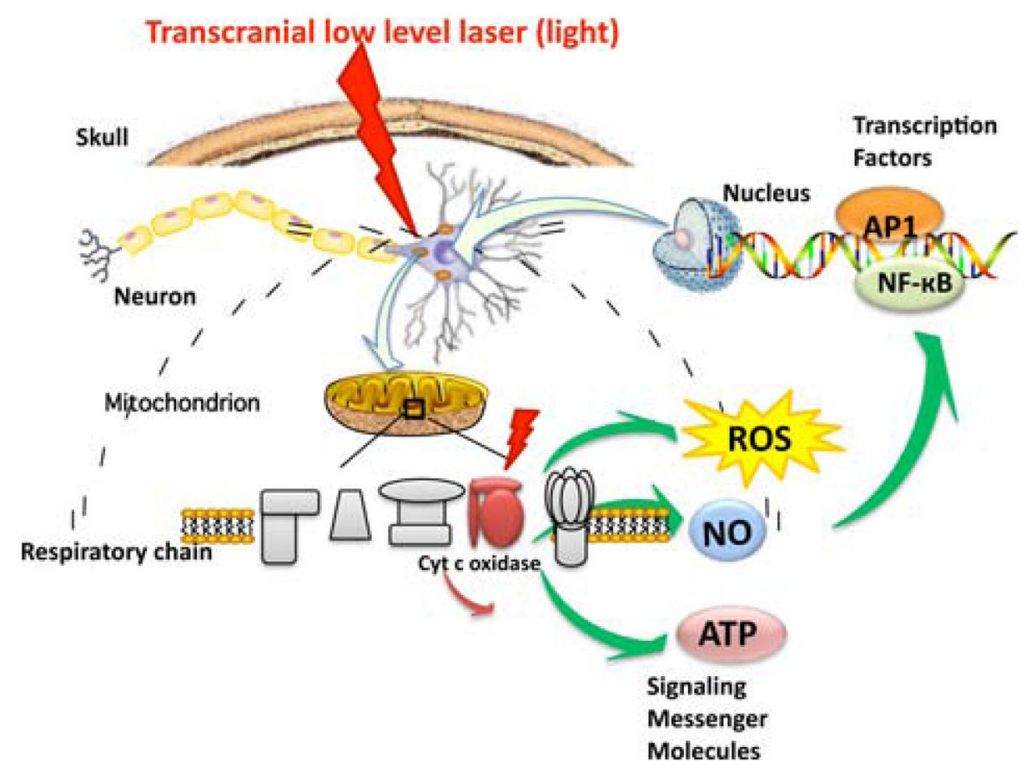

Figure 1.

Molecular mechanisms of transcranial LLLT. Light passes through the scalp and the skull, whereupon it is absorbed by cytochrome c oxidase in the mitochondrial respiratory chain of the cortical neurons. Cell signaling and messenger molecules are upregulated as a result of stimulated mitochondrial activity, including reactive oxygen species (ROS), nitric oxide (NO), and adenosine triphosphate (ATP). These signaling molecules activate transcription factors including NF- $\kappa \mathrm{B}$ and $\mathrm{AP}-1$ that enter the nucleus and cause transcription of a range of new gene products. 


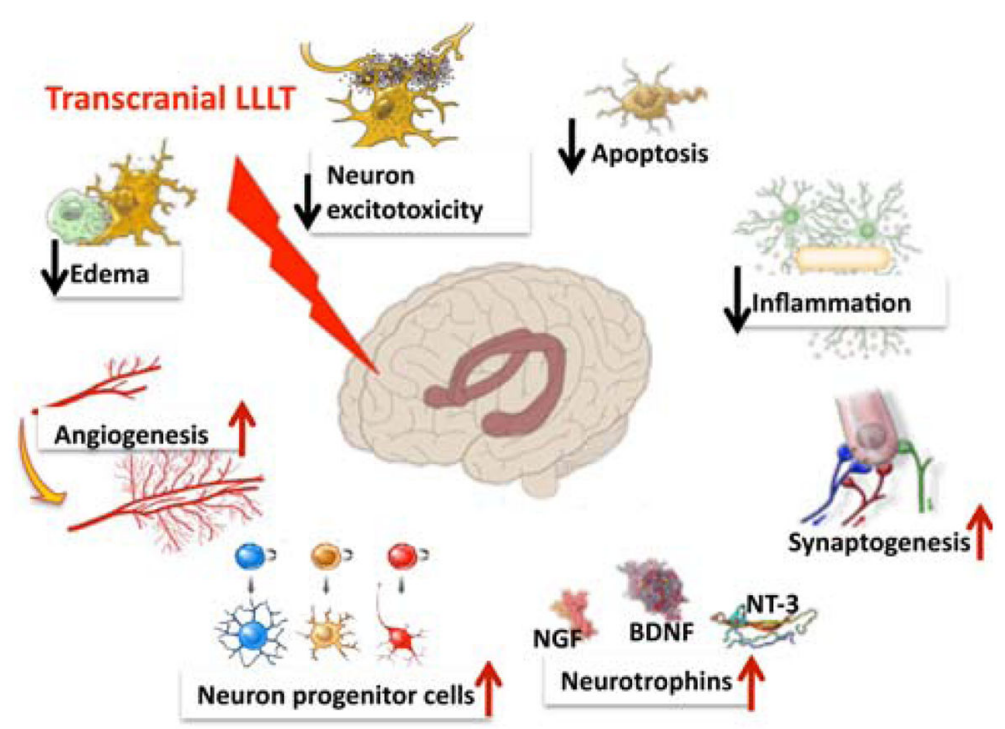

Figure 2.

Functional mechanisms of transcranial LLLT. The gene transcription described in Figure 1 can lead to decreases in neuronal apoptosis and excitotoxicity and lessening of inflammation and edema that will help reduce progressive brain damage. Increases in angiogenesis, expression of neurotrophins leading to activation of neural progenitor cells and incrar4sed synaptogenesis may all contribute to the brain repairing itself from damage sustained in the trauma. 


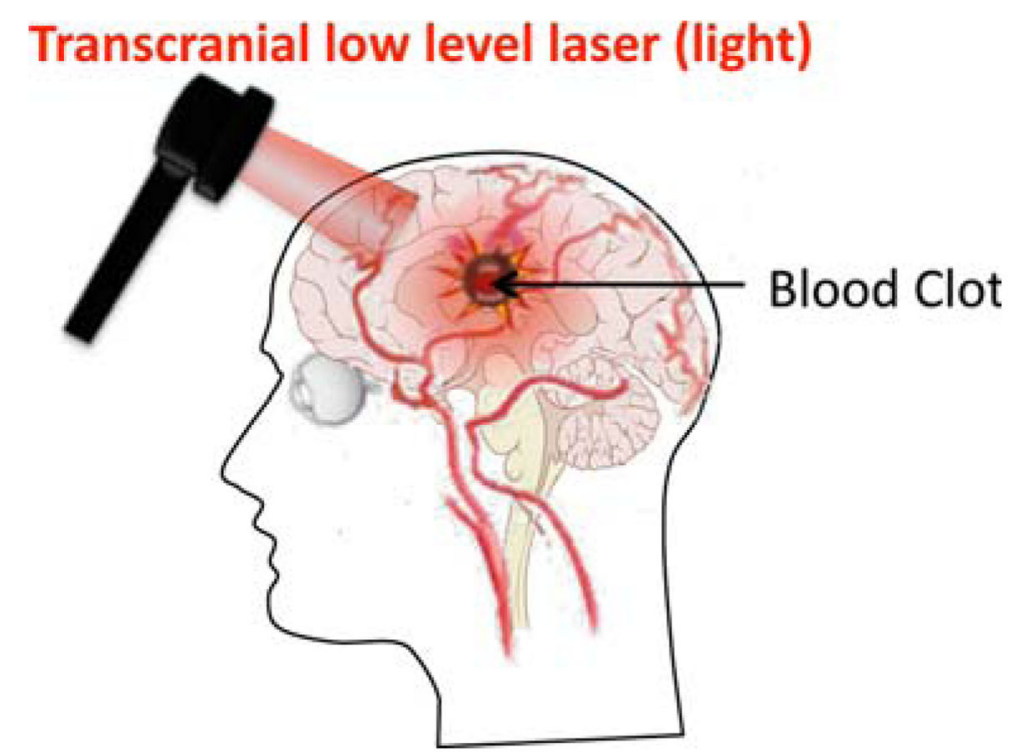

Figure 3.

Schematic of transcranial LLLT employed for stroke. $808 \mathrm{~nm}$ laser spot sequentially applied twenty times to cover the whole head. 

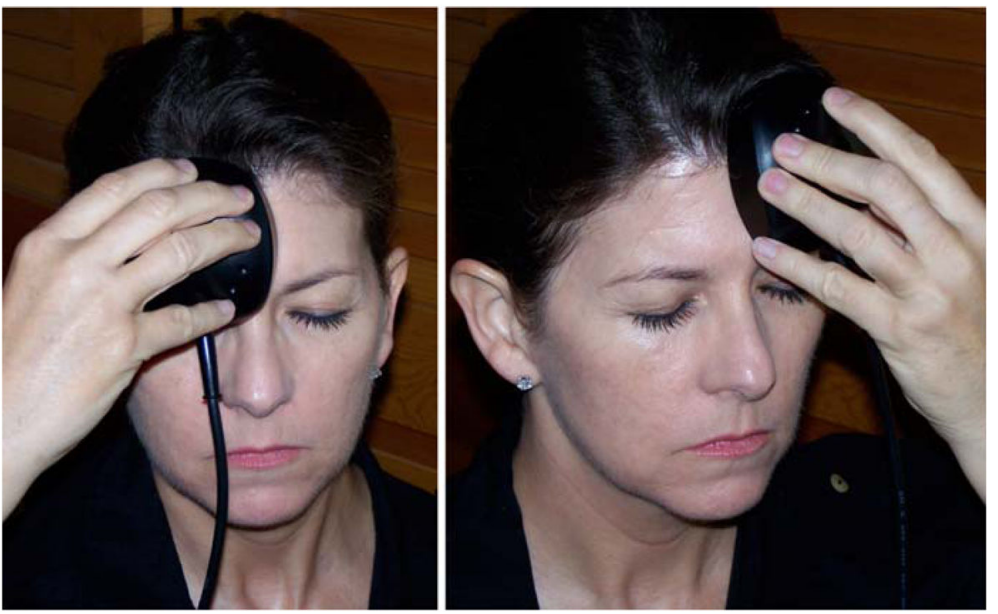

Figure 4.

Transcranial LLLT for chronic TBI. Showing right and left forehead placement areas for transcranial LED treatments performed by the patient at home, using a single, circularshaped cluster head. The usual treatment time is 10 minutes per area $\left(13.3 \mathrm{~J} / \mathrm{cm}^{2}\right)$. Reprinted with permission from Naeser et al. [55]. 

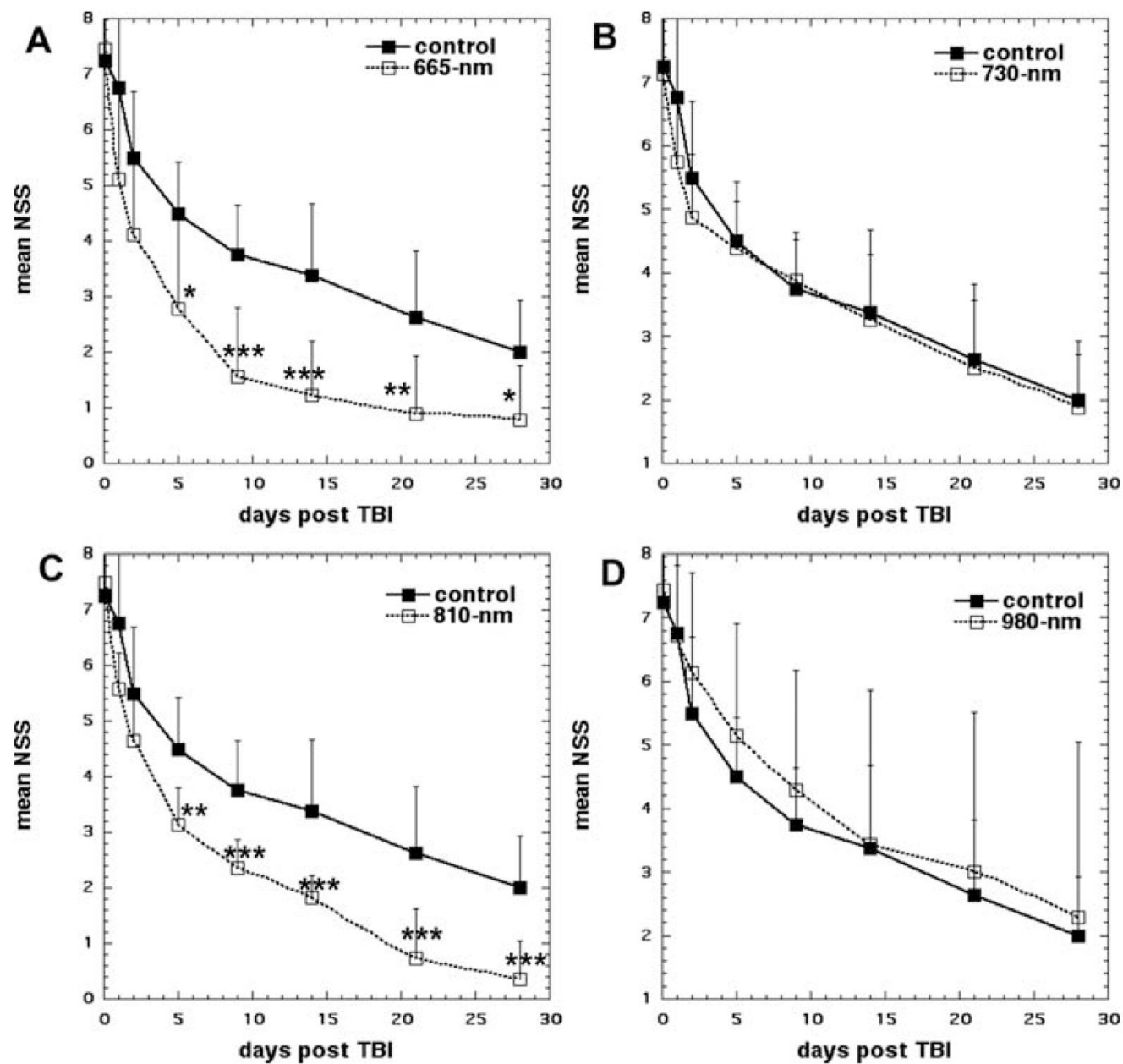

Figure 5.

Effect of different laser wavelengths in transcranial LLLT in closed head TBI in mice. Time course of NSS scores of sham and laser-treated mice. (A) Sham-treated control vs $665 \mathrm{~nm}$ laser, (B) Sham-treated control vs. $730 \mathrm{~nm}$ laser, (C) Sham-treated control vs. $810 \mathrm{~nm}$ laser, (D) Sham-treated control vs. $980 \mathrm{~nm}$ laser, Points are means of 8-12 mice and bars are SD. ${ }^{*} p<0.05 ; * *<0.01 ; * * p<0.001$ (one-way ANOVA). Reprinted with permission from $\mathrm{Wu}$ et al. [58]. 


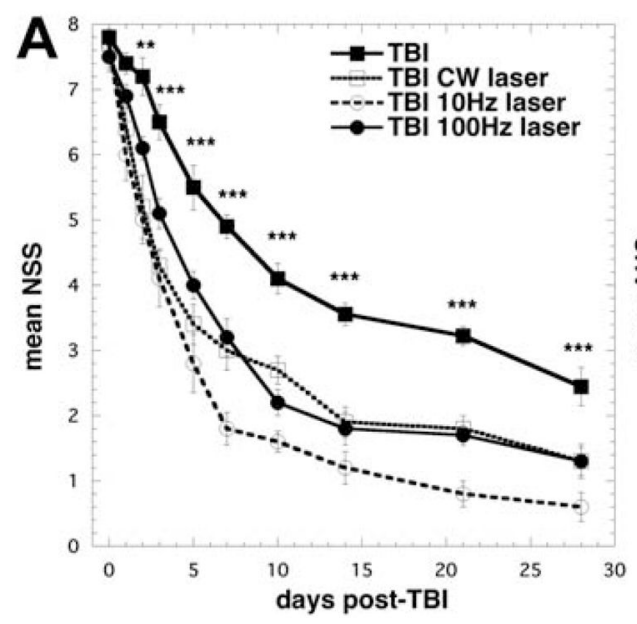

B

Figure 6.

Effect of pulsing in transcranial LLLT for CCI-TBI in mice. (A) Time course of neurological severity score (NSS) of mice with TBI receiving either control (no laser-treatment), or 810 $\mathrm{nm}$ laser $\left(36 \mathrm{~J} / \mathrm{cm}^{2}\right.$ delivered at $50 \mathrm{~mW} / \mathrm{cm}^{2}$ with a spot size of $\left.0.78 \mathrm{~cm}^{2}\right)$ in either $\mathrm{CW}, \mathrm{PW}$ $10 \mathrm{~Hz}$ or PW $100 \mathrm{~Hz}$ modes. Results are expressed as mean \pm S.E.M $(n=10)$. $* * * P<0.001$ vs. the other conditions.

Mean areas under the NSS-time curves in the two-dimensional coordinate system over the 28 -day study for the 4 groups of mice. Results are means $\pm \operatorname{SD}(n=10)$. Reprinted with permission from Ando et al. [60]. 


\section{Table 1}

Reports of transcranial LLLT used for stroke in animal models.

\begin{tabular}{|c|c|c|c|c|}
\hline Subject & Stroke model & Parameters & Effect & References \\
\hline Rat & MCAO & $\begin{array}{l}660 \mathrm{~nm} ; 8.8 \mathrm{~mW} ; 2.64 \mathrm{~J} / \mathrm{cm}^{2} \text {; pulse frequency } 10 \mathrm{kHz} \text {. } \\
\text { Laser was applied at cerebrum at } 1 ; 5 \text { and } 10 \text { minutes }\end{array}$ & $\begin{array}{l}\text { Suppression of NOS activity and up } \\
\text { regulation of TGF-b1 }\end{array}$ & {$[45]$} \\
\hline Rabbit & RSCEM & $\begin{array}{l}808 \pm 5 \mathrm{~nm} ; 7.5 \mathrm{~mW} / \mathrm{cm}^{2}, 2 \text { minutes duration } 3 \mathrm{~h} \text { after } \\
\text { stroke and } 25 \mathrm{~mW} / \mathrm{cm}^{2} 10 \text { minutes duration } 1 \text { or } 6 \text { hours } \\
\text { after stroke }\end{array}$ & $\begin{array}{l}\text { Improvement behavioral performance } \\
\text { and durable effect with LLLT within } 6 \\
\text { hours from stroke onset }\end{array}$ & {$[48]$} \\
\hline Rat & MCAO & $\begin{array}{l}808 \mathrm{~nm} ; 7.5 \mathrm{~mW} / \mathrm{cm}^{2} ; 0.9 \mathrm{~J} / \mathrm{cm}^{2} ; 3.6 \mathrm{~J} / \mathrm{cm}^{2} \text { at cortical } \\
\text { surface; CW and } 70 \mathrm{~Hz}, 4 \mathrm{~mm} \text { diameter }\end{array}$ & $\begin{array}{l}\text { Administration of LLLT after } 24 \text { hours } \\
\text { after stroke onset induces functional } \\
\text { benefit and mechanism of neurogenesis } \\
\text { induction }\end{array}$ & {$[46]$} \\
\hline Rat & MCAO & $\begin{array}{l}808 \mathrm{~nm} ; 0.5 \mathrm{~mW} / \mathrm{cm}^{2} ; 0.9 \mathrm{~J} / \mathrm{cm}^{2} \text { on brain } 3 \mathrm{~mm} \text { dorsal to } \\
\text { the eye and } 2 \mathrm{~mm} \text { anterior to the ear }\end{array}$ & $\begin{array}{l}\text { LLLT applied at different location in the } \\
\text { skull improve neurological function } \\
\text { after acute stroke }\end{array}$ & {$[63]$} \\
\hline Rabbit & RSCEM & $\begin{array}{l}808 \mathrm{~nm} ; 7.5 \mathrm{~mW} / \mathrm{cm}^{2} ; 0.9 \mathrm{~J} / \mathrm{cm}^{2} ; 3.6 \mathrm{~J} / \mathrm{cm}^{2} \text { at cortical } \\
\text { surface; CW; } 300 \mu \mathrm{s} ; \text { pulse at } 1 \mathrm{kHz}, 2 \mathrm{~ms} \text { at } 100 \mathrm{~Hz}\end{array}$ & $\begin{array}{l}\text { LLLT administered } 6 \text { hours after } \\
\text { embolic stroke results in clinical } \\
\text { improvements in rabbits }\end{array}$ & [64] \\
\hline
\end{tabular}




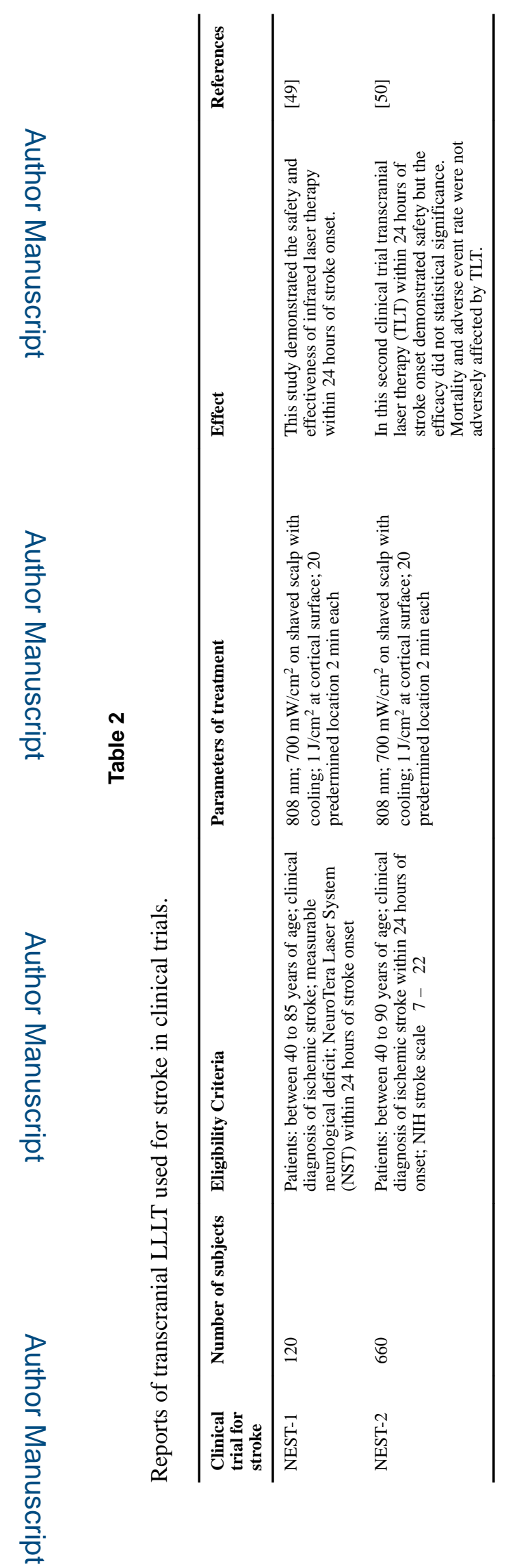

J Biophotonics. Author manuscript; available in PMC 2017 April 04. 